\title{
THE CORRELATION BETWEEN STUDENTS' DISCIPLINE AND ENGLISH LEARNING ACHIEVEMENT AT THE SECOND GRADE OF SMA NEGERI 3 BAUBAU
}

\section{Baharudin}

Dosen Program Studi Pendidikan Bahasa Inggris FKIP Unidayan Baubau

\begin{abstract}
ABSTRAK
Tujuan utama penelitian ini adalah untuk menyelidiki hubungan kedisplinan siswa dengan prestasi belajar bahasa Inggris kelas dua SMA Negeri 3 Baubau. Angket kedisiplinan dan tes prestasi belajar siswa diujikan kepada 56 siswa SMA Negeri 3 Baubau sebagai respondent penelitian ini. Hasil analisis data menunjukkan kedisiplinan siswa berkorelasi tinggi dan signifikan terhadap prestasi belajar bahasa Inggris siswa SMA Negeri 3 Baubau. Dengan nilai $r=0.648$, Sig or $p<\alpha(0.000<0.05)$. Penelitian ini juga menunjukkan bahwa kedisiplinan siswa berada dalam kategori sedang dan prestasi bahasa Inggris siswa kelas dua SMA Negeri 3 Baubau dalam kategori rendah.
\end{abstract}

\section{INTRODUCTION}

Longman dictionary of Contemporary English (2005) define discipline as to teach someone to obey rules and control their behavior or to punish someone in order to keep order and control. It implies that discipline urge someone to obey the rule and control one's behavior. Discipline is associated with the act of teaching students self-control based on a contract that binds a teacher and a group of students together so that learning can be more effective (Harmer in Rahimi \& Karkami, 2015). Thus, emphasis is put on student self-regulation by negotiating, discussing, and contracting between teachers and students (Vitto, 2003).

While classroom discipline according to Ur (1996: 270) is a state in which both teacher and learners accept and consistently observe a set of rules about behavior in the classroom whose function is to facilitate smooth and efficient teaching and learning in a lesson. Ur adds the existence of a disciplined classroom does not, it itself, necessarily imply that learning is take place. Simply because the activities had themselves little learning value. It indicate that discipline is paramount important for learning success but it should be interconnected with other variable.

The significance of classroom discipline and management has been appreciated both from a social practice perspective and an effective teaching stand. Socially, teachers' classroom discipline has been suggested to be a potent force to promote students' sense of responsibility in the classroom (Lewis, Romi, Qui, \& Katz, 2005) and to produce more responsible citizens at a grand vision (Lewis, 2001). Effective teaching research also shows that a sufficient degree of classroom discipline is needed to create an atmosphere conducive to student learning as students' misbehavior distracts the process of learning and teaching and ruins the effectiveness of even the most carefully planned lessons. 
Teachers' behavior and management styles attach a special significance to this issue as the intervention techniques teachers choose to manage their classes are perceived to be the sign of their professional adequacy by students (McCormick \& Shi, 1999) and an important motivator of learning. A non-threatening learning environment develops a sense of belonging among students, makes them selfinitiated and self-confident (Rogers, 1983), and thus increases their desire for learning. Conversely, if teachers act coercively by adopting punitive discipline strategies, learning is negatively affected and more psychological and somatic complaints are heard in the classroom (Sava, 2002). This issue complicates teacher role in the classroom and makes dealing with persistent behavior problems a formidable challenge that is one source of teacher job stress and burnout.

Further, teachers and their caring behavior are considered to be among the most important environmental factors that can help learners to develop positive attitudes towards language learning and promote students' effort or engagement in doing language learning tasks. As a result, second language motivation research places a heavy emphasis on teachers' role in motivating language learners and minimizing the level of their demotivation (Dörnyei, 1994).
However, it is still unknown to what extent the contribution of the students' discipline to the learning achievement in learning a foreign language. The aim of the present study is, First, to investigate the degree of students' discipline and learning achievement. Second, to find out the relationship between these variables and find out to what extent the contribution of discipline to learning achievement does.

The researcher's main reason in taking this research with the consideration and the result of pre-observation as well as sharing information with some of the teachers as teaching practitioners. one of the teacher said that many students got the lack of students' classroom discipline and it is assumed will affect their academic success. Besides that, if it is viewed from the students' learning achievement in learning English, it was under the standard values; in this case, their result of learning English was not like as the teacher expected. Besides that, a part of the students' parents in educating and guiding the children learning was as another consideration factor.

Based on the above description, the researcher is interested in conducting the research under the title "The Correlation between students discipline and English Learning Achievement at the second grade of SMA Negeri 3 Baubau".

\section{METHOD OF THE RESEARCH}

\section{Participant}

The participant in this study included 56 students in Grade 2 of SMA Negeri 3 Baubau, Southeast Sulawesi. It is taken from proportional random sampling and come from different classes by using class random selection. These SMA are located in Baubau, Souteast Sulawesi and have different major such as social science (IPS) and natural science (IPA). 


\section{Instruments}

The data were collected through the following instruments:

1) Questionnaire was used to find out the data of students' discipline. It used Likert scale model and it was made in checklist form. Students' learning discipline questionnaire consist of 30 statement develop from three indicators; loyalty, obedient, and orderly. The option of the questionnaire consists of four levels ranging from 1 to 4 . The score 2 shows 'strongly disagree' in contrast the score 4 shows 'strongly agree'.

2) Test was used to measure the students' Foreign language (FL) learning achievement. The test was in multiple test form consisting of 32 learning achievement items. The material was adapted from second grade English textbook for senior high school. The test was made from blueprint. The test contains reading and speaking skill, language component such as grammar and vocabulary.

\section{Procedure}

The questionnaire and test were administered to 56 FL learners in penciland-paper format. The participants received all instruments in one session to make sure all the participant participate in the same time and number of the students. First; they took the learning achievement test, they complete the test in 80 minutes; then after a 30 minutes break and refreshment, they completed the rest one questionnaire (students' discipline questionnaire) in 20 minute. The questionnaire and test were calculated descriptively. Then the hypothesis was analysed with simple regression analysis the help of SPSS program for windows.

\section{FINDING AND DISCUSSION}

\section{Descriptive Analysis}

The result of students' discipline questionnaire shows that the highest score is 114 and the lowest score is 94 , the mode is 78 and the median is 82.5. Based on the statistical calculation the mean score of the students is 84.2 , and standard deviation is 9.08. The result of students' learning achievement test shows that the highest score is 94 and the lowest score is 28 , the mode is 78 and the median is 65.6. Based on the statistical calculation the mean score of the students is 64.7 , and standard deviation is 15.3. The amount of simple correlation that state the extent of relationship of students' discipline and learning achievement is .648 with determinant coefficient $\left(r^{2}\right)$ is 0.42 . it means that $42 \%$ variety of students' learning achievement is determined by the degree of students' discipline, the rest $58 \%$ is determined by other factors that is not observed in this research. The detail information about variables description can be seen in table 1 and model summary of statistical calculation was shown in table 2. 
Table 1. The Summary of Variables Description

\begin{tabular}{clcc}
\hline No. & Variable & $\begin{array}{c}\text { Students' } \\
\text { discipline }\end{array}$ & $\begin{array}{c}\text { Learning } \\
\text { achievement }\end{array}$ \\
\hline 1. & Mean & 84.23 & 64.74 \\
2. & Median & 82.5 & 65.6 \\
3. & Mode & 78 & 78 \\
4. & Std. Deviation & 9.08 & 15.3 \\
5. & Minimum & 70 & 28 \\
6. & Maximum & 114 & 94 \\
\hline
\end{tabular}

Table 2. Model Summary

\begin{tabular}{|c|c|c|c|c|}
\hline Model & R & R Square & $\begin{array}{c}\text { Adjusted R } \\
\text { Square }\end{array}$ & $\begin{array}{c}\text { Std. Error of the } \\
\text { Estimate }\end{array}$ \\
\hline 1 & $.648^{\mathrm{a}}$ & .420 & .409 & 11.775 \\
\hline
\end{tabular}

a. Predictors: (Constant), $\mathrm{X}$

\section{Inferential Analysis}

The result of statistical regression analysis meaningfulness test shows that $F_{\text {observed }}$ is 39.084 with probability value or sig $=0.000$. because the significance on $\alpha=0.000<0.05$, so the regression (the increase and decrease) that happened to the students' learning achievement as a result of variation of students' discipline could be accepted in this research.

The result of regression coefficient meaningfulness test shows that: (1) the constant of $b 0=-27.326$ not significant with probability value 0.071 , while (2) the coefficient of $b 1=1.093$ significant with probability value $\operatorname{sig}=0.000$. Therefore, regression model which explain the correlation between students learning achievement with the independent variable hypothesized in this research is $\hat{Y}=-27.326$ $+1.093 \mathrm{X}$. the result of statistical regression analysis can be seen in table 3 and 4 .

Table 3. ANOVA ${ }^{\mathrm{b}}$

\begin{tabular}{|c|c|c|c|c|c|c|}
\hline \multicolumn{2}{|c|}{ Model } & \multirow{2}{*}{$\begin{array}{c}\begin{array}{c}\text { Sum of } \\
\text { Squares }\end{array} \\
5418.821\end{array}$} & \multirow{2}{*}{$\begin{array}{r}\text { df } \\
1\end{array}$} & \multirow{2}{*}{$\begin{array}{c}\begin{array}{c}\text { Mean } \\
\text { Square }\end{array} \\
5418.821\end{array}$} & \multirow{2}{*}{$\frac{\mathbf{F}}{39.084}$} & \multirow{2}{*}{$\frac{\text { Sig. }}{.000^{\mathrm{a}}}$} \\
\hline 1 & Regression & & & & & \\
\hline & Residual & 7486.833 & 54 & 138.645 & & \\
\hline & Total & 12905.654 & 55 & & & \\
\hline
\end{tabular}

a. Predictors: (Constant), $\mathrm{X}$

b. Dependent Variable: Y 
Table 4. Coefficients ${ }^{\mathrm{a}}$

\begin{tabular}{|c|r|r|r|r|c|}
\hline \multirow{2}{*}{ Model } & \multicolumn{2}{|c|}{$\begin{array}{c}\text { Unstandardized } \\
\text { Coefficients }\end{array}$} & $\begin{array}{c}\text { Standardized } \\
\text { Coefficients }\end{array}$ & & \multirow{2}{*}{ S } \\
\cline { 2 - 4 } & \multicolumn{1}{|c|}{ B } & Std. Error & Beta & \multicolumn{1}{c|}{ S } & \multicolumn{1}{c|}{ Sig. } \\
\hline 1 (Constant) & -27.326 & 14.810 & & -1.845 & .071 \\
X & 1.093 & .175 & .648 & 6.252 & .000 \\
\hline
\end{tabular}

a. Dependent Variable: $\mathrm{Y}$

\section{Discussion}

The result of the statistical calculation of students' discipline questionnaire the mean score of the students is 84.2, and standard deviation is 9.08. Based on the score category the students' discipline are low (44.64\%) with the most frequency 25 (see table 5). It can be concluded that the students' discipline are low because most of the students are in the low category.

Table 5. Score Category of Students' Discipline

\begin{tabular}{|c|c|c|c|c|}
\hline No & Score & Category & Frequency & Percentage \\
\hline 1. & $X \geq \bar{x}+1 . S D$ & Very high & 7 & $12.5 \%$ \\
\hline 2. & $\bar{x}+1 . S D>X \geq \bar{x}$ & High & 19 & $33.93 \%$ \\
\hline 3. & $\bar{x}>X \geq \bar{x}-1 . S D$ & Low & 25 & $44.64 \%$ \\
\hline 4. & $X<\bar{x}-1 . S D$ & Very low & 5 & $8.93 \%$ \\
\hline \multicolumn{3}{|c|}{ Total } & 56 & $100 \%$ \\
\hline
\end{tabular}

While the statistical calculation of the students' learning achievement the mean score of the students is 64.7 , and standard deviation is 15.3. based on the score category that students' learning achievement test are moderate (39.29\%) with the most frequency 22 (see table 6). It can be concluded that the students' learning achievement are moderate because most of the students are in the moderate category.

Table 6. Score Category of Students' Learning Achievement

\begin{tabular}{cccc}
\hline $\begin{array}{c}\text { Scoring } \\
\text { range }\end{array}$ & Category & Frequency & Percentage \\
\hline $86-100$ & Very good & 5 & $8.93 \%$ \\
$71-85$ & Good & 16 & $28.57 \%$ \\
$56-70$ & Moderate & 22 & $39.29 \%$ \\
$\leq 55$ & Low & 13 & $23.21 \%$ \\
\hline \multicolumn{2}{r}{ Total } & $\mathbf{5 6}$ & $\mathbf{1 0 0 \%}$ \\
\hline
\end{tabular}

The result of correlation analysis test shows that the correlation between students' discipline and learning achievement is 0.648 which is significant at the probability level 0.000 . Because probability value is lower than 0.05 . It means that $\mathrm{HO}$ is rejected and $\mathrm{Ha}$ is accepted. It can be concluded that students' discipline and learning achievement denote a positive and high correlation. The strong and high correlation between the students' discipline and learning achievement means that students' discipline is imperative in mediating students' learning achievement. This finding is consistent with several studies that have demonstrated students' learning achievement is influenced by the students' leaning discipline. Study conducted by Rahimi and Karkami, 2015) 
implied that classroom discipline affect the students' learning achievement and motivation. Furthermore, research conducted by Stanley (2014) indicated the finding of the study that effective school discipline should be encouraged in controlling students' behavior thus affects students' general academic performance.

The finding of the present research also implied that the higher correlation also indicated that the higher the students' learning discipline the higher their foreign language learning achievement. A nonthreatening learning environment develops a sense of belonging among students, makes them self-initiated and self-confident (Rogers, 1983), and thus increases their desire for learning. socially, teachers' classroom discipline has been suggested to be a potent force to promote students' sense of responsibility in the classroom (Lewis, Romi, Qui, \& Katz, 2005) and to produce more responsible citizens at a grand vision (Lewis, 2001).

Further, teachers and their caring behavior are considered to be among the most important environmental factors that can help learners to develop positive attitudes towards language learning and promote students' effort or engagement in doing language learning tasks. As a result, second language achievement and motivation research places a heavy emphasis on teachers' role in mediating motivating language learners and minimizing the level of their demotivation (Dörnyei, 1994).

\section{REFERENCES}

Brown, H. D. 2001. Teaching by Principles. White Plains, NY: Pearson Education LTD.

Dornyei, Z. 1994. Motivation and Motivating in the foreign language classroom. The Modern Language Journal, 78, 273-284.

Lewis, R. 2001. Classroom Discipline and Student Responsibility: The students' view. Teaching and Teacher Education, 17, 307-319.

Lewis, R., Romi, S., Qui., X., \& Katz, Y. 2005. A comparison of teachers' classroom discipline in Australia, China and Israel. Teaching and Teacher Education, 21, 729-741.

Mardapi, D. (2008). Teknik penyusunan instrument tes dan nontes. Jokjakarta: MITRA CENDEKIA.
McCormick, J., \& Shi, G. 1999. Teachers' attributions for responsibility for their occupational stress in the People's Republic of China and Australia. British Journal of Educational Psychology, 69, 393407.

Rahimi, M. \& Karkami, F.H. 2015. The role of teachers' classroom discipline in their teaching effectiveness and students language learning motivation and achievement: A path method. Iranian Journal of Language Teaching Research, 3 (1), 57-82.

Pane, D. 2010. Viewing classroom discipline as negotiable social interaction: A communities of practice perspective. Teaching and Teacher Education, 26, 87-97. 
Sava, F. A. 2002. Causes and Effects of Teacher Conflict-inducing Attitudes towards Pupils: A path analysis model. Teaching and Teacher Education, 18, 1007-1021.

Stanley, E.O. 2014. Discipline and Academic Performance (A study of selected secondary schools in Lagos, Nigeria). International Journal of Academic Research in Progressive Education and Development, Vol. 3, No. 1, 181194.
Sugiyono. 2011. Statistika untuk Penelitian. Bandung: Alfabeta.

Ur, Penny. 1996. A course in Language Teaching. Practice and theory. Cambridge. Cambridge University Press.

Vitto, J. M. 2003. Relationship-driven Classroom Management: Strategies that promote student motivation. Thousand Oaks, CA: Corwin Press. 